\title{
Clinico-Hematological Study of Pancytopenia in Adults at a Tertiary Care Center
}

\author{
Harshita Vaibhaw ${ }^{1}$, E. Girikumar', Dilip Hari Mandke ${ }^{3}$, Ravi Nandan Prasad Sinha ${ }^{4}$ \\ ${ }^{1}$ Assistant Professor, Department of Pathology, Great Eastern Medical School \& Hospital, Srikakulam, Andhra Pradesh, ${ }^{2}$ Professor \& Head, Department of \\ Pathology, Great Eastern Medical School \& Hospital, Srikakulam, Andhra Pradesh, ${ }^{3}$ Professor, Department of Pathology, Great Eastern Medical School \& Hospital, \\ Srikakulam, Andhra Pradesh, ${ }^{4}$ Professor, Department of Pathology, Darbhanga Medical College, Darbhanga, Bihar.
}

\section{Abstract}

Background: Pancytopenia is one of the important haematological derangements. Thorough investigation for ascertaining the cause is important. Subjects and Methods: The present cross-sectional study was conducted upon 112 patients of pancytopenia. Profile of the patients, clinical features and findings of haematological investigations and bone marrow aspiration were noted. Results: Mean age of the patients was $46.7 \pm 9.3$ years. Pallor was seen in all the patients. Megaloblastic anemia was present in 36.6\%, acute leukemia in 11.6\%, hypersplenism and lymphoprofilerative disorder each in $10.7 \%$. Conclusion: Hematological investigations and bone marrow aspiration in patients suffering from pancytopenia is useful.

Keywords: Adults, Clinical, Hematological, Pancytopenia.

Corresponding Author: Dr. Harshita Vaibhaw, Assistant Professor, Department of Pathology, Great Eastern Medical School \& Hospital, Aditya Educational Society, Ragolu Village, Srikakulam, Andhra Pradesh, Pin-532484.

Received: January 2019

Accepted: February 2019

\section{Introduction}

The reduction in all the three formed elements of blood: red blood cells, white blood cells and platelets is known as pancytopenia. $^{[1]}$ It is one of the important haematological derangements seen. It results from either marrow suppression or marrow infiltration and causes may range from transient marrow failure to acute hematological malignancies. ${ }^{[2]}$

Pallor, prolonged fever and a tendency to bleed must lead to suspicion of marrow failure and it must be investigated thoroughly. In different population groups, the diseases may vary with their differences in age, nutritional status and prevalence of infection and lead to pancytopenia. ${ }^{[3]}$ Thorough physical examination, clinical history and peripheral blood picture are the necessary tools for diagnosing pancytopenia. Bone marrow aspiration is a gold standard for the diagnosis of the cause of pancytopenia. ${ }^{[4]}$

\section{Aims \& objectives}

The present study was conducted to identify different underlying causes of pancytopenia and to assess the clinical features.

\section{Subjects and Methods}

The present cross-sectional study was conducted at Great Eastern Medical School \& Hospital, Srikakulam, Andhra
Pradesh. Patients admitted in the department of medicine who were diagnosed to be suffering from pancytopenia were included in the present study. Patients of hematological malignancy, those receiving blood transfusion in last one month and those receiving drugs known to suppress bone marrow were excluded. A total of 112 patients were included in the present study.

Detailed clinical history and thorough physical examination was done for each patient. EDTA anticoagulated blood (2ml) was collected, processed through automated differential cell analyzer and hematological parameters were calculated. Peripheral blood Pancytopenia was defined as hemoglobin $(\mathrm{Hb}) \leq 10 \mathrm{~g} / \mathrm{dL}$, absolute neutrophil count $\leq$ $1500 / \mu \mathrm{l}$, platelet count $\leq 100000 / \mu \mathrm{l}$. Bone marrow aspiration was done and findings were noted to find the cause of pancytopenia.

Data was recorded in pretested proforma, entered in Microsoft Excel and analyzed by SPSS v 16.0. Appropriate summarization and statistical tests were done. Tests of significance were done and p-value of less than 0.05 was considered to be statistically significant.

\section{Results}

A total of 112 patients were included in the present study. Mean age of the patients was $46.7 \pm 9.3$ years. There was male preponderance. Table- 1 shows the clinical features of the patients of pancytopenia. Pallor was seen in all the 
patients. $73.2 \%$ patients suffered from fever, weakness in $44.6 \%$, splenomegaly in $28.6 \%$ and bleeding manifestation in $13.4 \%$.

Table 1: Clinical features seen
\begin{tabular}{|l|l|l|l|}
\hline Clinical features* & $\begin{array}{l}\text { Frequency } \\
(\mathbf{n = 1 1 2})\end{array}$ & $\%$ & $\mathbf{9 5 \%}$ CI \\
\hline Pallor & 112 & 100 & $96.7-100$ \\
\hline Fever & 82 & 73.2 & $64.3-80.5$ \\
\hline Weakness & 50 & 44.6 & $35.8-53.9$ \\
\hline Splenomegaly & 32 & 28.6 & $21-37.5$ \\
\hline $\begin{array}{l}\text { Bleeding } \\
\text { Manifestation }\end{array}$ & 15 & 13.4 & $8.3-20.9$ \\
\hline Loss of Apetite & 47 & 42 & $33.2-51.2$ \\
\hline
\end{tabular} - multiple response

[Table 2] shows the hematological disorders causing pancytopenia. Megaloblastic anemia was present in 36.6\%, acute leukemia in 11.6\%, hypersplenism and lymphoprofilerative disorder each in $10.7 \%$, Myelodysplastic syndrome in $6.3 \%$ and haemolytic anemia in $2.7 \%$.

Table 2: Hematological Disorders Causing Pancytopenia.

\begin{tabular}{|l|l|l|l|}
\hline Hematological Disorders & $\begin{array}{l}\text { Frequency } \\
(\mathbf{n = 1 1 2})\end{array}$ & $\mathbf{\%}$ & $\mathbf{9 5 \%}$ CI \\
\hline Megaloblastic anemia & 41 & 36.6 & $28.3-45.8$ \\
\hline Acute leukemia & 13 & 11.6 & $6.9-18.9$ \\
\hline Aplastic anemia & 10 & 8.9 & $4.9-15.7$ \\
\hline $\begin{array}{l}\text { Lymphoproliferative } \\
\text { disorder }\end{array}$ & 10 & 8.9 & $4.9-15.7$ \\
\hline Myelodysplastic syndrome & 7 & 6.3 & $3.1-12.3$ \\
\hline Hypersplenism & 12 & 10.7 & $6.2-17.8$ \\
\hline Hemolytic anemias & 3 & 2.7 & $0.9-7.6$ \\
\hline Drug induced & 2 & 1.8 & $0.5-6.3$ \\
\hline Others & 12 & 10.7 & $6.2-17.8$ \\
\hline
\end{tabular}

\section{Discussion}

A total of 112 patients of pancytopenia were studied. Mean age of the patients was $46.7 \pm 9.3$ years. There was male preponderance. Ghartimagar et al found that patients' age ranged from 2 to 82 years with a mean age of 43.95 years, and there was male predominance. ${ }^{[5]}$ Mansuri et al found that age of the patients ranged from 1 to 70 years with a slight male predominance. Most common age group was 11-20 years. ${ }^{[6]}$ Patel et al observed that the age of the patients ranged from 15-85 years with male preponderance. ${ }^{[7]}$ Momin et al noted that the age of patients ranged from 2 to 85 years with a mean age of 43 years. There was male preponderance. ${ }^{[8]}$ Thakkar et al found that age of the patients ranged from 13 to 86 years with a mean age of 42.9 years and slight male predominance. ${ }^{[9]}$

The patients presented with pallor $(100 \%)$, fever $(73.2 \%)$, weakness (44.6\%), splenomegaly (28.6\%) and bleeding manifestation (13.4\%). Ghartimagar et al found that most of the patients presented with generalized weakness, pallor, dypnoea and fever. ${ }^{[5]}$ Mansuri et al found that most of the patients presented with generalized weakness and fever. The commonest physical finding was pallor, followed by splenomegaly and hepatomegaly. ${ }^{[6]}$ Patel et al observed that the most common clinical features were weakness $(80 \%)$, fever $(72.1 \%)$, pallor $(100 \%)$ and hepatomegaly $(62.8 \%) .{ }^{[7]}$ Momin et al noted that fever and generalized weakness were common clinical presentations. The commonest physical finding was pallor and splenomegaly on systemic examination. ${ }^{[8]}$ Thakkar et al found that most of the patients presented with generalized weakness and fever. The commonest physical finding was pallor, followed by splenomegaly and hepatomegaly. ${ }^{[9]}$

Megaloblastic anemia (36.6\%), acute leukemia (11.6\%), hypersplenism and lymphoprofilerative disorder (10.7\%), Myelodysplastic syndrome $(6.3 \%)$ and haemolytic anemia $(2.7 \%)$ were the major causes of pancytopenia. Ghartimagar et al found hypoplastic marrow in $27.5 \%$ cases, followed by $18.8 \%$ cases of megaloblastic anemia and $13.76 \%$ cases of acute leukemia. Other findings included one case each of hemophagocyosis, leishmaniasis, plasmodium vivex malaria and metastatic carcinoma. ${ }^{[5]}$ The commonest marrow finding of Mansuri et al was hyper cellularity with megaloblastic erythropoiesis. The commonest cause for pancytopenia was megaloblastic anemia. ${ }^{[6]}$ Normocytic normochromic was the predominant blood picture in the study done by Patel et al who found that common causes of pancytopenia were malaria (50\%), megaloblastic anemia $(18.6 \%)$ and dengue $(18.1 \%)$ followed by hypersplenism $(7.1 \%) \&$ iron deficiency anemia(2.7\%). ${ }^{[7]}$ Momin et al found that the commonest peripheral smear was dimorphic picture \& commonest bone marrow finding was hypercellular marrow with megaloblastic erythroid hyperplasia. The commonest cause for pancytopenia was Megaloblastic anemia (34\%) followed by Hematolymphoid malignancy $(26.6 \%) .^{[8]}$ The commonest marrow finding of Thakkar et al was hypercellularity with megaloblastic erythropoiesis. The commonest cause for pancytopenia was megaloblastic anemia followed by malaria. ${ }^{[9]}$

\section{Conclusion}

It is concluded from the present study that detailed hematological investigations along with bone marrow aspiration in patients suffering from pancytopenia can be helpful in identifying the underlying cause.

\section{References}

1. Freedman MH, Nelson Textbook of Paediatrics 19th edition, South East Asia; Elsevier Academic Press Ltd. 2011:1684.

2. Niazi N, Raziq F. The incidence of underlying pathology in pancytopenia - An experience of 89 cases. J Postgrad Med Inst. 2004; 18:76-79.

3. Javalgi AP, Dombale VD. Clinico-hematological analysis of pancytopenia: A bone marrow study. National Journal of Laboratory Medicine 2013, 2(4):12-17.

4. Ishtiaq O, Baqai HZ, Anwer F, Hussain N. Patterns of pancytopenia patients in a general medical ward and a proposed diagnostic approach. J Ayub Med Coll Abbottabad. 2004 Jan-Mar;16(1):8-13.

5. Ghartimagar D, Ghosh A, Thapa S, Sapkota D, Jhunjhunwala AK, Narasimhan R, Talwar OP. Clinicohematological Study of Pancytopenia in a Tertiary Care Hospital of Western Region of Nepal. J Nepal Med Assoc 2017;56(207):319-24.

6. Mansuri B, Thekdi KP. A prospective study among cases of the 
pancytopenia on the basis of clinic-hematological analysis and bone marrow aspiration. Int J Res Med Sci. 2017 Aug;5(8):3545-9.

7. Patel RR, Tambekar M, Dhar R. Clinico-hematological analysis of pancytopenia in adults - A two year prospective studyAnnals of Pathology and Laboratory Medicine, Vol. 5, Issue 2, February, 2018 123-8.

8. Momin M, Ingle A, Aluri A, Reddy KMG, Prusty BSK. PANCYTOPENIA-Clinico-Hematological Study in a Capital City of
Telangana State -India. Saudi J. Med. Pharm. Sci. 2018; 4(4): $397-$ 405.

9. Thakkar BB, Bhavsar UN, Trivedi NJ, Agnihotri AS A study of pancytopenia in adult patients more than 12 years of age in north-west region of Saurashtra.. National Journal of Medical Research 2013; 3(1):48-53.

Copyright: (C) the author(s), 2019. It is an open-access article distributed under the terms of the Creative Commons Attribution License (CC BY 4.0), which permits authors to retain ownership of the copyright for their content, and allow anyone to download, reuse, reprint, modify, distribute and/or copy the content as long as the original authors and source are cited.

How to cite this article: Vaibhaw H, Girikumar E, Mandke DH, Sinha RNP. Clinico-Hematological Study of Pancytopenia in Adults at a Tertiary Care Center. Asian J. Med. Res. 2019;8(1):PT08-PT10.

DOI: dx.doi.org/10.21276/ajmr.2019.8.1.PT3 